J. Amer. Soc. Hort. SCI. 120(5):877-881. 1995.

\title{
The Effect of Day and Night Temperature and Irradiance on Development of Catharanthus roseus (L.) 'Grape Cooler'
}

\author{
Grace M. Pietsch ${ }^{1}$, William H. Carlson', Royal D. Heins ${ }^{2}$, and James E. Faust ${ }^{1}$ \\ Department of Horticulture, Michigan State University, East Lansing, MI 48824
}

Additional index words. Madagascar vinca, plant modeling

\begin{abstract}
The effects of day and night temperatures (15 to 35C) and three irradiance levels [50\% of ambient, ambient, and ambient plus $12 \mathrm{~mol} \cdot \mathrm{m}^{-2} \cdot \mathrm{day}^{-1}$ of supplemental photosynthetic photon flux (PPF)] on development of Catharanthus roseus 'Grape Cooler' were determined. Time to flower decreased by 30 days and leaf-pair unfolding rate (LUR) increased linearly as average daily temperature increased from 18 to 35C. Flower size was greatest when plants were grown at $25 \mathrm{C}$. Supplemental light decreased days to flower and increased flower size. Flowering occurred when nine leaf pairs were present on the plant. Using the inverse of the LUR curve, i.e., days per leaf pair, the number of days to flower could be predicted at any time during plant development based on plant leaf number.
\end{abstract}

The U.S. bedding plant industry produces over 1.5 billion plug seedlings each year (Dill, 1993). One bedding plant species especially tolerant of high summer temperatures is Catharanthus roseus, or Madagascar vinca, which accounted for $3.6 \%$ of bedding plant flat sales in 1993 (Behe and Beckett, 1993).

When temperatures fall between the base temperature (temperature at which growth rate is zero) and the optimum temperature, development rate can be described by a linear function of average daily temperature (ADT) (Heins and Erwin, 1990; Ritchie and NeSmith, 1991). This linear relationship has been demonstrated in several flowering species, including poinsettia (Berghage and Heins, 1991; Berghage et al., 1990), Easter lily (Erwin et al., 1989), chrysanthemum (Karlsson et al., 1989), hibiscus (Karlsson et al., 1991), geranium (Armitage et al., 1981; Heins, 1979; White and Warrington, 1988), and impatiens (Lee et al., 1990).

The photosynthetic photon flux (PPF) a plant receives can influence flowering time and size. Karlsson et al. (1989) showed that, as PPF increased, time to flower decreased and inflorescence diameter increased in chrysanthemums. Carpenter and Beck (1973) found that 4 weeks of supplemental lighting caused earlier-flowering, shorter, more-compact impatiens, marigolds, petunias, and zinnias. Graper et al. (1990) showed that 5 to 10 days of supplemental lighting decreased time to flower in lo-day-old petunia seedlings. Earlier flowering of plants treated with supplemental lighting results from flower initiation occurring at a node that developed earlier or from warmer average plant temperatures as a result of the thermal radiation and heating from lamps (unpublished data).

The effects of supplemental PPF and the quantitative response of vinca to temperature have not been studied. The objective of this experiment was to quantify the effects of light and temperature on vinca development rate and flowering.

\footnotetext{
Received for publication 4 Nov. 1994. Accepted for publication 15 Mar. 1995. We acknowledge the support of the Western Michigan Bedding Plant Association. The cost of publishing this paper was defrayed in part by the payment of page charges. Under postal regulations, this paper therefore must be hereby marked advertisement solely to indicate this fact.

'Former graduate research assistant.

${ }^{2}$ Professor of horticulture.
}

\section{Materials and Methods}

Experiment 1. Five $4.0 \times 4.7-\mathrm{m}$ greenhouse sections with three $0.9 \times 2.7-\mathrm{m}$ benches were maintained at constant $15,20,25,30$, or 35C. Plants on each bench were exposed to a different PPF level: ambient solar radiation ( $18 \mathrm{~mol} \cdot \mathrm{m}^{-2} \cdot \mathrm{day}^{-1}$ average $), 50 \%$ of ambient as a result of shading with mesh shadecloth, and ambient plus 250 to $300 \mu \mathrm{mol} \cdot \mathrm{m}^{-2} \cdot \mathrm{s}^{-1}$ for $12 \mathrm{~h} /$ day $\left(10.8\right.$ to $\left.13.0 \mathrm{~mol} \cdot \mathrm{m}^{-2} \cdot \mathrm{day}^{-1}\right)$ provided by two $400-\mathrm{W}$ high-pressure sodium (HPS) lamps.

Plug trays of g-week-old Catharanthus roseus 'Grape Cooler' plants were transplanted into 804-cell packs (eight $150-\mathrm{cm}^{3} 4$-cell packs per $29 \times 58-\mathrm{cm}$ flat) filled with Baccto potting medium (Michigan Peat Co., Houston) on 5 Mar. 1992. There were three replications, each consisting of one flat. Each flat was assigned a day and night temperature, light level, and replication number. Flats were moved every $12 \mathrm{~h}$ among the five greenhouse sections to provide 25 day temperature (DT) and night temperature (NT) treatments. Plants under constant temperature were rearranged each time the other plants were moved. Days to first flower, to $50 \%$ of plants in flower per flat, and to $100 \%$ of plants in flower per flat were recorded.

Experiment 2. Plugs were received and transplanted 15 Mar. 1993 and were used as a verification of the 1992 experiment. Plants were given the same treatment as those used the previous year except that the supplemental PPF was $200 \mu \mathrm{mol} \cdot \mathrm{m}^{-2} \cdot \mathrm{s}^{-1}\left(8.6 \mathrm{~mol} \cdot \mathrm{m}^{-2} \cdot \mathrm{day}^{-1}\right)$.

Leaf-pair number was counted at transplant. Flower diameter and number of leaf nodes were recorded as each plant came into flower. The uppermost leaf pair on plants that received constant temperature treatments were marked, and leaf-pair numbers were counted every other day,

Flowering data for both years were converted to rates, and linear regression lines were calculated. Slopes and intercepts were compared for statistical differences using the procedure by Snedecor and Cochran (1967). The inverse of each regression line was calculated and plotted to create a curve predicting days to flower.

Linear regression analysis was performed on leaf-pair numbers collected to determine leaf-pair unfolding rates (LURs) as a function of average daily temperature. The slope $\left(b_{1}\right)$ and y intercept $\left(b_{0}\right)$ of each line were used to calculate the base temperature $\left(-b_{0} / b_{1}\right)$ and number of degree days required for one leaf pair to develop $\left(1 / b_{1}\right)$. The inverse of each LUR curve was calculated and plotted to create a predictive curve for days required for one leaf pair to unfold. 


\section{Results}

Time to flower decreased as ADT increased (Fig. 1 a-c) without regard to the way temperature was delivered during the daily cycle, i.e., warmer days and cooler nights vs. cooler days and warmer nights. In both experiments, plants with au ADT of 15 or $17.5 \mathrm{C}$ under ambient or $50 \%$ shade conditions had not flowered when the experiments ended 8 weeks after transplant (15 weeks from seeding). Plants under supplemental light flowered earlier than those at the other two light levels, but also did not flower under an ADT of $15 \mathrm{C}$ by the end of the experiment. Flowering occurred in as few as 20 days from transplant at $35 \mathrm{C}$.

There were no statistical differences between regression lines of flower development rate vs. temperature for plants grown under $50 \%$ shade when years were compared (Table 1). There was a significant difference (5\% level) in the slope between years for plants grown under ambient light. While statistically significant, the difference between the slopes between the 2 years was judged horticulturally insignificant. Data for the 2 years were therefore pooled for the shade and ambient light treatments. However, the slope and intercept were significantly different for the supplemen-

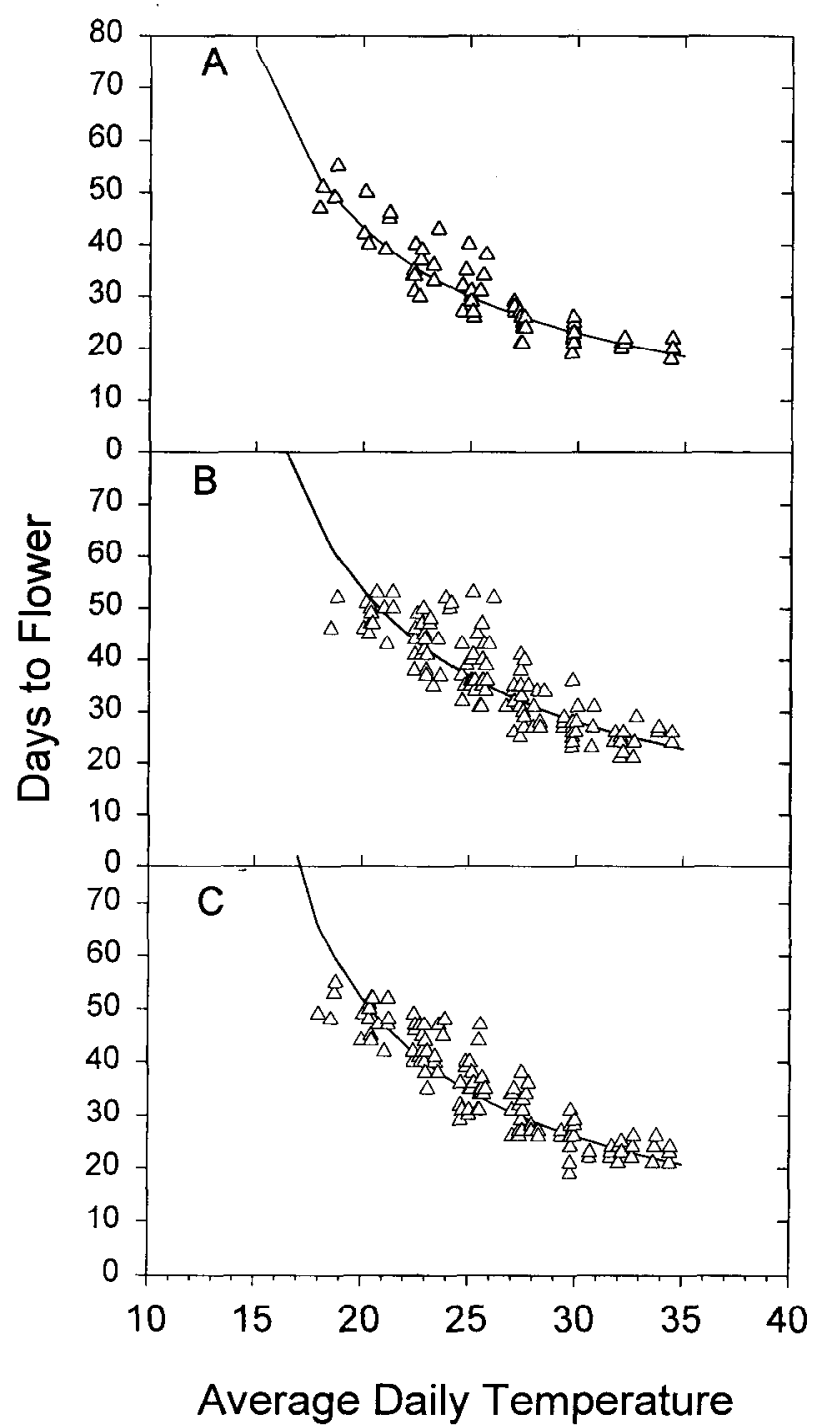

tal lighting treatment between years; both years' data therefore were not pooled. Only data from 1993 are shown in Fig. 1.

LUR increased linearly as air temperature increased for all light levels (Fig. 2). LUR regression lines for ambient and supplemental light treatments were statistically parallel, although plants grown under supplemental light had a higher LUR than those under natural light at the same air temperature. LUR under $50 \%$ shade increased at a slower rate as temperature increased than LUR in the natural or supplemental light treatments.

Thermal time required for one leaf pair to develop varied from 82 to 127 degree days, with base temperatures varying from 10 to 11.9C (Table 2). Thermal time required for one leaf pair to develop decreased as irradiance increased.

The time required for one leaf pair to unfold decreased from 12 to 4 days as temperature increased from 20 to $35 \mathrm{C}$ (Table 3 ). There was an average of 9.3 leaf pairs on plants when flowering occurred, and the average number of leaf pairs unfolded at the time the plugs were transplanted was 4.9 ; therefore, about 4.4 leaf pairs developed after transplant and before flowering.

The LUR model (Fig. 2) was compared with that of time to flower (Fig. 1) by comparing the number of days required for 4.4

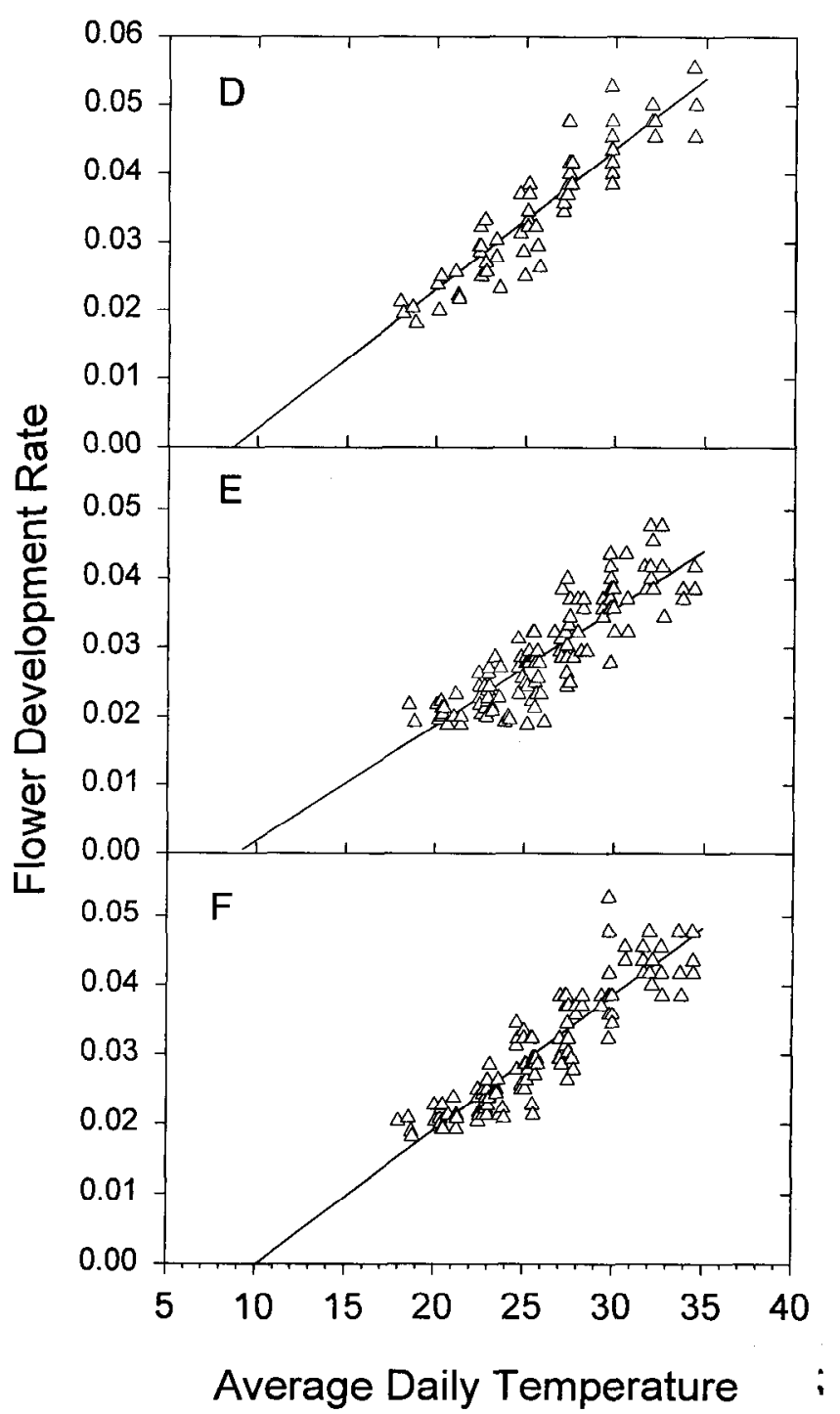

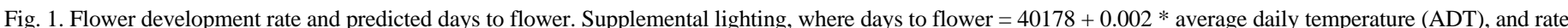
of progress to flower $=1 /(4.0178+0.002 *$ ADT $)($ A and D). Ambient light, where days to flower $=4.0198+0.0019 *$ ADT and rate of progress to flower $=1 /(-0.0198$ $+0.0019 *$ ADT $)(\mathbf{B}$ and $\mathbf{E})$. Shade $(50 \%)$, where days to flower $=-0.0151+0.0017 *$ ADT, and rate of progress to flower $=1 /(-0.0151+0.0017 *$ ADT $)(\mathbf{C}$ and $\mathbf{F})$. 
Table 1. Regression analysis for 'Grape Cooler' vinca flower development rate between years. Flower development rate $=b_{0}+$ $\mathrm{b}_{1}$ [average daily temperature (ADT)].

\begin{tabular}{lccrc}
\hline \hline Year & Variable & $50 \%$ shade & Ambient & Supplemental \\
\hline 1992 & $\mathbf{b}_{0}$ & -0.0155 & -0.0206 & -0.0094 \\
& $-\mathbf{b}_{1}$ & 0.0017 & 0.0020 & 0.0017 \\
1993 & $\mathrm{~b}_{0}$ & -0.0152 & -0.0191 & -0.0178 \\
& $\mathrm{~b}_{1}$ & 0.0017 & 0.0019 & 0.0020 \\
Comparison of slopes & & $\mathrm{F}=0.0245^{\mathrm{Ns}}$ & $\mathrm{F}=5.1235^{*}$ & $\mathrm{~F}=8.5223^{* *}$ \\
Comparison of intercepts & & $\mathrm{F}=2.4157^{\mathrm{Ns}}$ & $\mathrm{F}=3.0977^{\mathrm{Ns}}$ & $\mathrm{F}=3.1543^{*}$ \\
\hline
\end{tabular}

Ns, $* * *$ Nonsignificant or significant at $P=0.05$ and 0.01 , respectively.

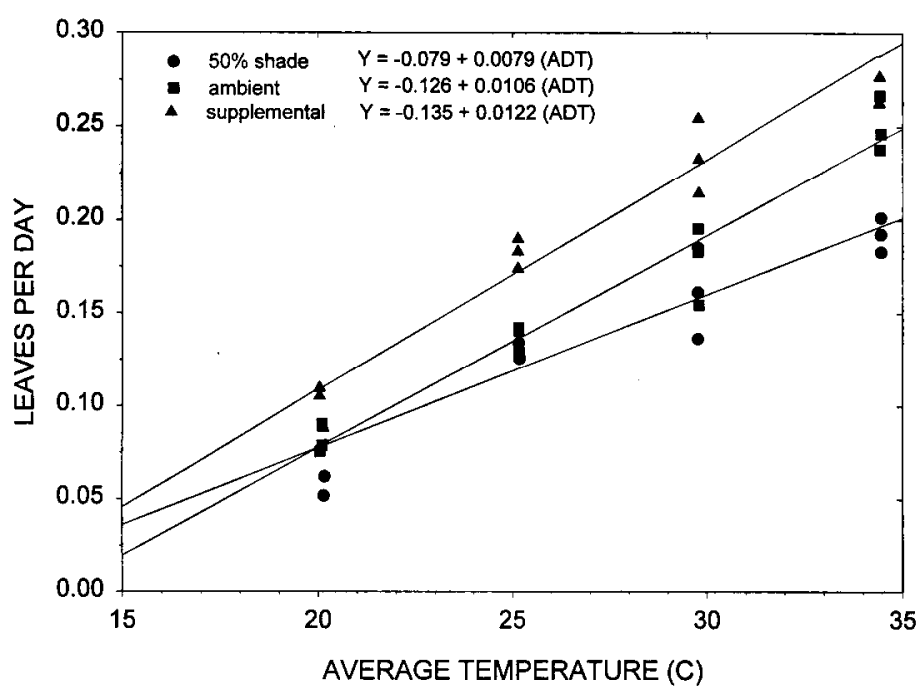

Fig. 2. Relationship between average daily temperature (ADT) and Catharanthus roseus L. 'Grape Cooler' leaf-pair unfolding rate (LUR) for $50 \%$ shade $(\bullet)$, $\operatorname{ambient}(\nabla)$, and supplemental light $(\boldsymbol{\nabla})$. The regression lines are $\operatorname{LUR}_{(50 \% \text { shade }}$ $-0.078+0.0078($ ADT $), \operatorname{LUR}_{\text {(ambient) }}=-0.128+0.0106($ ADT $)$, and $\operatorname{LUR}_{\text {(supplemental) }}$ $=-0.136+0.0122(\mathrm{ADT})$.

Table 2. Calculated values for degree days/leaf pair and base temperature using leaf unfolding rate regression lines for 'Grape Cooler' vinca. Irradiance levels were equivalent to photosynthetic photon flux daily light integrals of about 9,18 , and $30 \mathrm{~mol} \cdot \mathrm{m}^{-2} \cdot \mathrm{day}^{-1}$ for the $50 \%$ shade, ambient, and supplemental irradiance treatments, respectively.

\begin{tabular}{|c|c|c|}
\hline Irradiance & Degree days/leaf & Base temp \\
\hline $50 \%$ Shade & 127 & 10.0 \\
\hline Ambient & 94 & 11.9 \\
\hline Supplemental & 82 & 11.1 \\
\hline
\end{tabular}

Table 3. Calculated days required for one leaf pair to unfold based on leaf unfolding rate regression lines for 'Grape Cooler' vinca. Irradiance levels were equivalent to photosynthetic photon flux daily light integrals of about 9,18 , and $30 \mathrm{~mol} \cdot \mathrm{m}^{-2} \cdot \mathrm{day}^{-1}$ for the $50 \%$ shade, ambient, and supplemental irradiance treatments, respectively.

\begin{tabular}{lccc}
\hline & \multicolumn{3}{c}{ Irradiance } \\
\cline { 2 - 4 } Temp & $50 \%$ Shade & Ambient & Supplemental \\
\hline 18 & 16 & 15 & 12 \\
20 & 13 & 12 & 9 \\
25 & 8 & 7 & 6 \\
30 & 6 & 5 & 4 \\
35 & 5 & 4 & 3 \\
\hline
\end{tabular}

leaf pairs to unfold with the predicted number of days to flower from transplant. Both models showed a similar number of days (Table 4). Therefore, the LUR model can be used to predict days to flower. Figure 3 shows predicted number of days to flower for plants with three (top line) to eight (bottom line) leaf pairs. The days to flower for a plant can be predicted from Fig. 3 by subtracting the current number of leaf pairs on a plant from 9.3 and selecting an average daily temperature.

Flower diameter was influenced by DT and irradiance level, but not by NT (Fig. 4). Flowers were largest at a day setting of $25 \mathrm{C}$ under supplemental light.

\section{Discussion}

The leaf development rate in vinca increased and time to flower decreased as temperature increased from 15 to 35C (Fig. I), indicating that vinca is more responsive to and tolerates continuous high temperatures (30 to 35C) (Scullin, 1991; Thomas and Gilbertz, 1992) better than many other ornamental species, such as poinsettia (Berghage et al., 1990; Faust and Heins, 1994), chrysanthemum (Karlsson et al., 1989), dahlia (Brøndum and Heins, 1993), hibiscus (Karlsson et al., 1991), Easter lily (Erwin and Heins, 1990), and African violet (Faust and Heins, 1993). Vinca plants grown at 35C in these experiments were of quality equal to those grown at lower temperatures.

Plants grown under the supplemental lighting treatment required fewer days to flower than those grown under the $50 \%$ shade and the ambient irradiance treatments. The beneficial developmental responses observed with HPS lamp treatments may be a result of increased plant temperatures. HPS lamps mounted above a plant canopy deliver about $0.74 \mathrm{~W} \cdot \mathrm{m}^{-2}(300$ to $100,000 \mathrm{~nm})$ per $\mu \mathrm{mol} \cdot \mathrm{m}^{-2} \cdot \mathrm{s}^{-1}$ (400 to $700 \mathrm{~nm}$ ) (Bubenheim et al., 1988). If this extra energy absorbed by the plant canopy is not dissipated by transpiration or convection, then plant temperatures increase. Measurement of vinca shoot-tip temperatures showed that those of plants under HPS lamps $\left(200 \mu \mathrm{mol} \cdot \mathrm{m}^{-2} \cdot \mathrm{s}^{-1}\right)$ were generally 2 to $3 \mathrm{C}$ higher than those under shadecloth and ambient light (data not shown). Similarly, Faust and Heins (unpublished data) observed a 1.5C increase in shoot-tip temperatures of vinca plants grown under HPS lamps that delivered $100 \mu \mathrm{mol} \cdot \mathrm{m}^{-2} \cdot \mathrm{s}^{-1}$. Graper and Healy (1991) showed that petunia leaf temperatures under HPS lamps delivering $167 \mu \mathrm{mol} \cdot \mathrm{m}^{-2} \cdot \mathrm{s}^{-1}$ were 4 to $5 \mathrm{C}$ higher than those of plants under ambient irradiance.

A comparison of the regression of leaf-pair unfolding rate of the supplemental lighting treatment with that of the other two irradiance treatments showed that the slopes were similar, but the $y$ intercepts were different. This relationship suggests that the faster flowering under the HPS lamps was a result of higher plant temperature as a result of the increased absorbed radiation. If we 
Table 4. Comparison of predicted days to flower from transplant and predicted days required for 4.4 leaf pairs to unfold for ' $G r a p e$ Cooler' vinca. Irradiance levels were equivalent to photosynthetic photon flux daily light integrals of about 9 , 18, and $30 \mathrm{~mol} \cdot \mathrm{m}^{-2} \cdot \mathrm{day}^{-1}$ for the $50 \%$ shade, ambient, and supplemental irradiance treatments, respectively.

\begin{tabular}{|c|c|c|c|c|c|c|}
\hline \multirow[b]{2}{*}{ Temp } & \multicolumn{2}{|c|}{$50 \%$ Shade } & \multicolumn{2}{|c|}{ Ambient } & \multicolumn{2}{|c|}{ Supplemental } \\
\hline & $\begin{array}{l}\text { 4.4 Leaf } \\
\text { pairs to } \\
\text { unfold }\end{array}$ & $\begin{array}{l}\text { Days to } \\
\text { flower }\end{array}$ & $\begin{array}{l}4.4 \text { Leaf } \\
\text { pairs to } \\
\text { unfold }\end{array}$ & $\begin{array}{l}\text { Days to } \\
\text { flower }\end{array}$ & $\begin{array}{l}4.4 \text { Leaf } \\
\text { pairs to } \\
\text { unfold }\end{array}$ & $\begin{array}{l}\text { Days to } \\
\text { flower }\end{array}$ \\
\hline$\overline{20}$ & 54 & 54 & 48 & 52 & 41 & 43 \\
\hline 25 & 37 & 37 & 31 & 35 & 27 & 30 \\
\hline 30 & 29 & 28 & 22 & 26 & 20 & 23 \\
\hline 35 & 23 & 23 & 18 & 21 & 16 & 19 \\
\hline
\end{tabular}

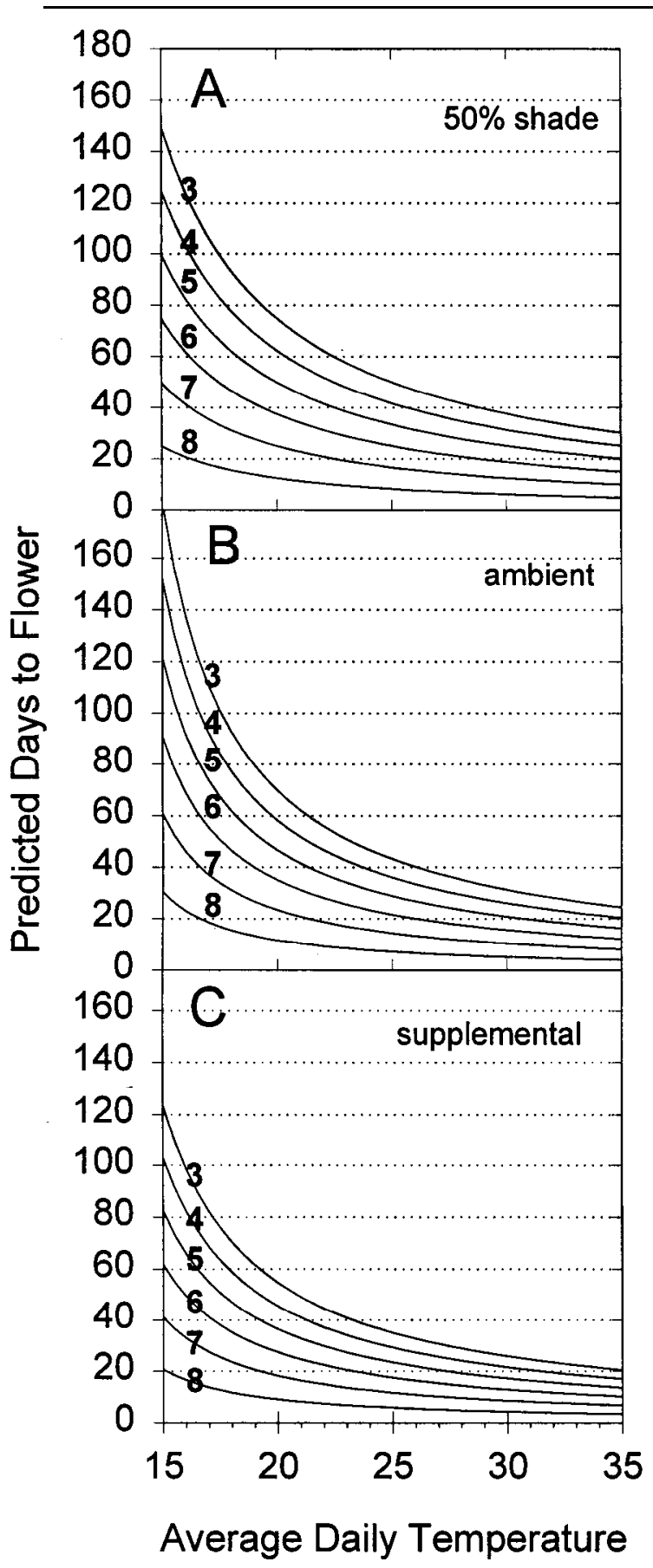

Fig. 3. Curves of predicted days to flower using predicted days required for one leaf pair to unfold. The numbers above each line represent the number of leaf pairs already on the plant. assume that the average daily plant temperature under the HPS lamps increased $2 \mathrm{C}$ and recalculate the supplemental lighting regression line in Fig. 2, then the regression line is identical to that of the ambient and 50\% treatments. Therefore, we believe that the increased leaf and flower development rates observed under the supplemental irradiance treatment were a result of increased shoot-tip temperatures, not increased irradiance alone.

The recommended greenhouse temperature for growing vinca is 15 to $18 \mathrm{C}$ NT (Nau, 1991); however, the predicted number of days required for one leaf pair to unfold decreases as temperature increases from 18 to 35C (Table 3). Thus, by increasing the air temperature from $18 \mathrm{C}$ to $35 \mathrm{C}$, the number of days required for one leaf pair to unfold decreases by 11 days, meaning that time to flower decreases by 55 days if five leaf pairs must unfold. A more realistic situation would be au increase from 20 to $25 \mathrm{C} \mathrm{NT}$, at which time to flower decreases by 2 to 3 weeks.

The prediction curves in Fig. 3 can be used by growers to determine temperatures necessary for flowering vinca for specific market dates. Their use requires a knowledge of plant leaf-pair number. Leaf-pair number subtracted from nine leaf pairs indicates how many leafpairs must develop before flowering. All days to flower and temperature combinations associated with that leafpair number are shown in Fig. 3 and can be used to determine greenhouse temperature setpoint.

In conclusion, optimal temperature for vinca production is about $25 \mathrm{C}$. Temperatures below $25 \mathrm{C}$ result in increased time to flower, and, while those above $25 \mathrm{C}$ result in faster leaf and flower development rates, flower size decreases.

\section{Literature Cited}

Armitage, A.M., W.H. Carlson, and J.A. Flore. 1981. The effect of temperature and quantum flux density on the morphology, physiology, and flowering of hybrid geraniums. J. Amer. Soc. Hort. Sci. 106:643647.

Behe, B. and L. Beckett. 1993. 1993 season sales summary. Professional Plant Growers Assn. News 24(12):2-19.

Berghage, R.D., R.D. Heins, and J.E. Erwin. 1990. Quantifying leaf unfolding in the poinsettia. Acta Hort. 272:243-247.

Berghage, R.D. and R.D. Heins. 1991. Quantification of temperature effects on stem elongation in poinsettias. J. Amer. Soc. Hort. Sci. 116:14-18.

Brøndum, J.J. and R.D. Heins. 1993. Modeling temperature and photoperiod effects on growth and development of dahlia. J. Amer. Soc. Hort. Sci. 118:36-42.

Bubenheim, D.L., B. Bugbee, and F.B. Salisbury. 1988. Radiation in controlled environments: Influence of lamp type and filter material. J. Amer. Soc. Hort. Sci. 113:468-474.

Carpenter, W.J. and G.R. Beck. 1973. High intensity supplementary lighting of bedding plants after transplanting. HortScience 8:483-484. Dill, R.A. 1993. Powerhouses of the plug industry. Greenhouse Grower 11(11):10-15. 

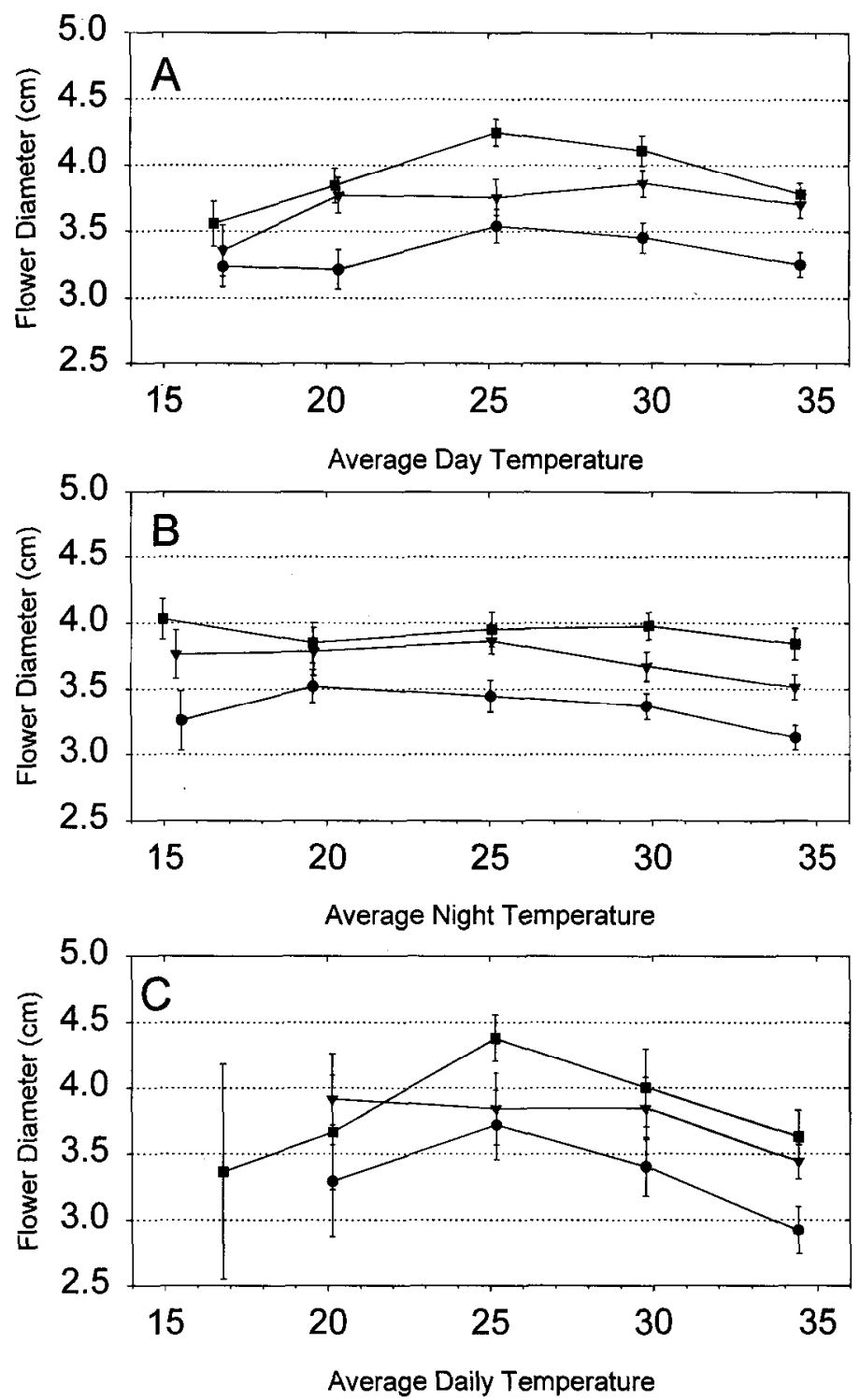

Fig. 4. Comparison of flower diameter under (a) average day temperature, (b) average night temperature, and (c) constant temperature. Error bars represent 95\% confidence intervals. Symbols: ( $) 50 \%$ shade, ( $\boldsymbol{\nabla}$ ) ambient light, ( supplemental light.
Erwin, J.E., R.D. Heins, and M.G. Karlsson. 1989. Thermomorphogenesis in Lilium longiflorum. Amer. J. Bot. 6(1):47-52.

Erwin, J.E. and R.D. Heins. 1990. Temperature effects on lily development rate and morphology from the visible bud stage until anthesis. J. Amer. Soc. Hort. Sci. 115:644-646.

Faust, J.E. and R.D. Heins. 1993. Modeling leaf development of the African violet (Saintpaulia ionantha Wendl.). J. Amer. Soc. Hort. Sci. 118:747-751.

Faust, J.E. and R.D. Heins. 1994. Axillary bud development of 'Red Sails' poinsettia is inhibited by high day temperatures. HortScience 29:544. (Abstr.)

Graper, D.F., W. Healy, and D. Lang. 1990. Supplemental irradiance control of petunia seedling growth at specific stages of development. Acta Hort. 272:153-157.

Graper, D.F. and W. Healy. 1991. High pressure sodium irradiation and infrared radiation accelerate Petunia seedling growth. J. Amer. Soc. Hort. Sci. 116:435-438.

Heins, R.D. 1979. Influence of temperature on flower development of geranium 'Sprinter Scarlet' from visible bud to flower. Bedding Plants, Inc. News (Dec):5.

Heins, R.D. and J. Erwin. 1990. Understanding and applying DIF. Greenhouse Grower 8(2):73-78.

Karlsson, M.G., R.D. Heins, J.E. Erwin, R.D. Berghage, W.H. Carlson, and J.A. Biembaum. 1989. Irradiance and temperature effects on time of development and flower size in chrysanthemum. Scientia Hort. 39:257267.

Karlsson, M.G., R.D. Heins, J.O. Gerberick, and M.E. Hackmann. 1991. Temperature driven leaf unfolding rate in Hibiscus rosa-senensis. Scientia Hort. 45:323-331.

Lee, W., J.E. Barrett, and T.A. Nell. 1990. High temperature effects on the growth and flowering of Impatiens wallerana cultivars. Acta Hort. 272:121-127.

Nau, J. 1991. Vinca, p. 782-784. In: V. Ball (ed.). Ball redbook. 15th ed. Geo. J. Ball Publishing, West Chicago, Ill.

Ritchie, J.T. and D.S. NeSmith. 1991. Temperature and crop development, p. 5-29. In: J. Hanks and J.T. Ritchie (eds.). Modeling plant and soil systems. Amer. Soc. of Agron., Madison, Wis.

Scullin, L. 1991. Production of annual vinca. Proc. Alabama Nurserymen's Summer Seminar, Alabama Nurserymen's Assn., Birmingham, Ala.

Snedecor, G.W. and W.G. Cochran. 1967. Statistical methods. 6th ed. Iowa State Univ. Press, Ames.

Thomas, P.A. and D.A. Gilbertz. 1992. Why can't you grow quality vinca? Greenhouse Manager 11(8):48-55.

White, J.W. and L.J. Warrington. 1988. Temperature and light integral effects on growth and flowering of hybrid geraniums. J. Amer. Soc. Hort. Sci. 113:354-359. 